\title{
Taikinių terapija - efektyviausias plaučių véžio gydymo būdas
}

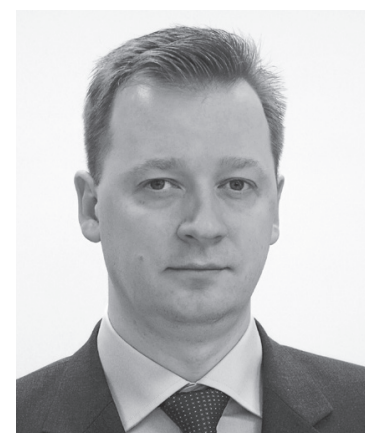

Marius Žemaitis

LSMU MA Pulmonologijos ir imunologijos klinika

Plaučių vežys - viena labiausiai paplitusių ir didžiausią mirtingumą sąlygojančių onkologinių ligų. Pasaulyje naujų plaučių vėžio atvejų skaičius artẻja prie $2 \mathrm{mln}$. Vèžio registro duomenimis, kasmet Lietuvoje plaučių vėžiu suserga apie pusantro tūkstančio žmonių, iš jų penkerius metus išgyvena tik 9,2 proc. moterų ir 8 proc. vyru [1, 2]. Nepaisant šiuolaikinių diagnostikos metodų, plaučių vežys nustatomas toli pažengęs, ir vienintelis gydymo būdas tèra sisteminis gydymas vaistais. Nors citotoksinė (nepageidaujamą, neretai gyvybei grẻsmingą, poveiki sukelianti) chemoterapija pailgina plaučių vė̌̌iu sergančių ligonių gyvenimo trukmę ir pagerina gyvenimo kokybę, daugelis mokslininkų ir tyrẻjų pripažista, kad chemoterapija yra pasiekusi savo galimybių ribas: didžiausias atsako i̇ gydymą dažnumas - 25-35 proc., 0 išgyvenamumo mediana - 8-10 mėnesių [3].

\section{IVADAS}

Pastaraisiais metais onkologinių ligų, iš jụ ir plaučiu vèžio, gydymo metodai, pritaikant molekulinès biologijos ir genetikos mokslo laimèjimus, sparčiai tobulèja. Vis svarbesnis vaidmuo kasdienèje klinikinèje praktikoje tenka taikiniu terapijai bei individualizuotam gydymui: esant epidermio augimo veiksnio receptoriaus (angl. epidermal growth factor receptor, EGFR) geno mutacijai ar anaplazinès limfomos receptoriaus tirozino kinazès (ALK) geno translokacijai skiriama tirozino kinazés inhibitoriu bei slopinama angiogenezè. Plaučiu véžio imunoterapija imunokontrolès taškų inhibitoriais, siekiant aktyvinti organizmo imunines ląsteles kovoti su vėžinėmis, - naujas gydymo būdas, ženkliai prailginantis plaučių vèžiu sergančiụjų gyvenimo trukmę lyginant su iprastine chemoterapija. Šiai dienai jau registruoti pirmieji imunoterapijos vaistai plaučių véžiui gydyti.

Lietuvoje nuo 2011 metų EGFR tirozino kinazès inhibitorių gefitinibą, o vèliau ir erlotinibą įtraukus ị Plaučiu véžio ambulatorinio gydymo, kurio išlaidos kompensuojamos iš Privalomojo sveikatos draudimo fondo biudžeto, tvarkos aprašą, sukaupta pakankamai klinikinès patirties gydant plaučiu vėži EGFR tirozino kinazès inhibitoriais.

EGFR yra žmogaus epidermio augimo veiksnio recep toriu (angl. human epidermal growth factor receptor, HER/ErbB) šeimos receptorinè tirozino kinazè. Jos padidejęs aktyvumas nustatomas esant ịvairiems navikams, taip pat nesmulkiụjų ląsteliụ plaučių véžiui (NSLPV). Padidèjęs EGFR aktyvumas dèl EGFR geno didesnès raiškos, amplifikacijos, aktyvinančiu mutaciju ar ligandu didesnès raiškos yra susijęs su kancerogenezès procesais. Kai kurie NSLPV navikai turi aktyvinančias EGFR geno mutacijas, kurios sukelia EGFR baltymų struktūros pokyčius, didinančius EGFR aktyvumą. EGFR tirozino kinazę galima slopinti tirozino kinazès inhibitoriais.

\section{GEFITINIBAS - PIRMASIS TAIKINIŲ TERAPIJOS VAISTAS PLAUČIIU VĖŽIUI GYDYTI}

Gefitinibas (Iressa) yra geriamasis selektyvus EGFR tirozino kinazès inhibitorius, blokuojantis autofosforilinimo 


\author{
Naujas gydymo būdas, ženkliai \\ prailginantis plaučių véžiu \\ sergančiųjų gyvenimo trukmę, \\ lyginant su iprastine chemoterapija
}

mechanizmą bei ląstelès signalo perdavimą ir veiksmingai gydantis navikus, kurie turi EGFR tirozino kinazès domeną aktyvinančių mutacijų. Gefitinibas - pirmasis taikinių terapijos vaistas, patvirtintas ES NSLPV gydyti.

II fazès klinikiniais tyrimais buvo nustatyta, kad bendroje NSLPV ligoniu populiacijoje, kai liga progresavo po pirmos arba antros eilès chemoterapijos, 42-54 proc. atvejų gydymas gefitinibu ligą sustabdè, o simptomų kontrolę palaikè 35-43 proc. atvejų $[4,5]$. Tačiau III fazès klinikinių tyrimų rezultatai bendroje NSLPV ligonių populiacijoje netikètai buvo neigiami: tirozino kinazès inhibitoriai, derinami su chemoterapija, nepailgino ligonių gyvenimo trukmès [6, 7].

Kodèl gauti tokie prieštaringi rezultatai, tuo metu nebuvo žinoma. Prieš minètus klinikinius tyrimus tam tikrai daliai ligonių (sergantiems bronchoalveoliniu plaučių vèžiu, nerūkantiems ir moterims) tirozino kinazès inhibitoriai kliniškai buvo veiksmingesni nei kitiems ligoniams. Šie faktai leido prieiti prie išvados, kad egzistuoja molekuliniai jautrumo tirozino kinazès inhibitoriams mechanizmai. Tai patvirtinta 2004 metais, kai nepriklausomai vienas nuo kito T. J. Lynch ir bendr. ir J. G. Paez ir bendr. nustatė, kad aktyvinančios geno EGFR mutacijos siejasi su NSLPV ligonių atsaku i gefitinibą. T. J. Lynch tyrime iš devynių ligonių, turẻjusių geno EGFR mutacijų, aštuoniems, o J. G. Paez visiems penkiems tirtiesiems nustatytas atsakas i gydymą gefitinibu. Tačiau atitinkamai nė vienam iš septynių ir keturių šių tyrimų dalyvių, kuriems geno EGFR mutacijų nerasta, klinikinio efekto nebuvo $[8,9]$.

Išsiaiškinta, kad navikiniame audinyje aktyvinančių EGFR geno mutacijų nustatoma $10-50$ proc. (10-15 proc. europiečių, apie 30-50 proc. azijiečių) pacientų, sergančių NSLPV.

Nuo tada duomenų apie EGFR tirozino kinazès inhibitorių veiksmingumą gydant NSLPV ligonius, kurių navikiniame plaučių audinyje nustatytos EGFR geno mutacijos, gauta atlikus keletą III fazès klinikinių tyrimų.

\section{GEFITINIBO VEIKSMINGUMAS ESANT AKTYVINANČIOMS EGFR GENO MUTACIJOMS}

I IPASS (angl. Iressa Pan-Asia Study), pirmąji III fazès klinikini atsitiktinių imčių tyrimą, atrinkta 1217 pacientụ remiantis klinikiniais atrankos kriterijais, leidžiančiais numatyti EGFR tirozino kinazès veiksmingumą (azijiečiai, nerūkantys ar anksčiau rūkę minimaliai, sergantys plaučių adenokarcinoma). Jie atsitiktinai paskirti i gefitinibo ar chemoterapijos (karboplatina ir paklitakseliu) grupę. Gydant gefitinibu, vienų metų išgyvenamumas be ligos progresavimo buvo reikšmingai didesnis (24,9 proc.), lyginant su ligoniais, kurie buvo gydyti chemoterapija (6,7 proc.). Ištyrus navikini audini, aktyvinančios EGFR geno mutacijos buvo nustatytos 59,7 proc. tiriamųjų. Grupeje ligonių, kuriems, radus aktyvinančią EGFR geno mutaciją, buvo skirtas gydymas gefitinibu, nustatytas reikšmingai didesnis atsako ì gydymą dažnumas (71,2 proc.) ir ilgesnis laikotarpis be ligos progresavimo (9,5 mèn.), lyginant su pacientais, kurie gydyti chemoterapija (atitinkamai 47,3 proc. ir 6,3 mèn.). Nesant aktyvinančių EGFR geno mutacijų, chemoterapija buvo veiksmingesnè už gefitinibą. Bendrojo išgyvenamumo rezultatai viršijo lūkesčius: ligonių gyvenimo trukmé pailgèjo net iki trijų kartų, lyginant su istoriniais duomenimis (22 mèn., palyginti su 8-10 mèn. standartinès chemoterapijos). Gefitinibas reikšmingiau pagerino ligonių gyvenimo kokybę bei sąlygojo mažiau nepageidaujamų reiškinių [10].

IPASS klinikinio tyrimo rezultatai iš esmès pakeitè plaučiuc vėžio gydymo standartus - įrodyta, kad, esant aktyvinančioms EGFR geno mutacijoms, gydymas EGFR tirozino kinazės inhibitoriais yra reikšmingai efektyvesnis nei standartinè chemoterapija, ir pacientu atranka gydymui turi būti grịsta ne klinikiniais, o molekuliniais genetiniais kriterijais. Remiantis šiuo klinikiniu tyrimu, nuo 2009 metu gefitinibas buvo rekomenduotas ir patvirtintas kaip pirmos eilès vaistas nustačius aktyvinančią EGFR geno mutaciją sergant NSLPV.

Vèlesni III fazès klinikiniai tyrimai buvo atlikti su ligoniais, kuriems nustatytos aktyvinančios EGFR geno mutacijos. Bendras atsako ì gydymą dažnumas (62,184,6 proc.), išgyvenamumo be ligos progresavimo mediana (8,0-10,8 mèn.) bei gyvenimo kokybės pagerejjimas buvo reikšmingai didesni gefitinibo grupeje, palyginti su chemoterapija (atitinkamai 30,7-37,5 proc. ir 5,4-6,6 mèn.). Bendro išgyvenamumo mediana siekè net iki 38,8 ménesių. Gydymas gefitinibu šiuose III fazès klinikiniuose tyrimuose buvo gerai toleruojamas, o nepageidaujamas poveikis reikšmingai retesnis nei standartinès chemoterapijos grupejje. Dažniausi nepageidaujami reiškiniai buvo išbèrimas - iki 66 proc. (tačiau tik 3 proc. $\geq 3$ laipsnio) bei viduriavimas - iki 47 proc. (tačiau tik 4 proc. $\geq 3$ laipsnio) [11-13].

Kadangi dauguma klinikinių tyrimų buvo vykdomi azijiečiu populiacijoje, 2013 metais pristatytas IV fazès klinikinis tyrimas, skirtas gefitinibo veiksmingumui ir saugumui esant aktyvinančiai EGFR geno mutacijai įvertinti baltųjų rasès populiacijoje. I tyrimą ịtraukti vyresni nei 18 metų IIIA-IV stadijos NSLPV sergantys ligoniai, 0-2 balų funkcinès būklès pagal ECOG, kuriems nustatyta aktyvinanti EGFR geno mutacija. Kaip pirmos eilès vaistą tiriamiesiems skirtas geriamasis gefitinibas - po $250 \mathrm{mg}$ 1 kartą per dieną. Pagrindinè vertinamoji baigtis - atsakas ì gydymą. Antrinès baigtys: ligos kontrolès dažnumas, išgyvenamumas be ligos progresavimo, bendras išgyvenamumas, saugumas. Iš 1060 atrankoje dalyvavusių tiriamųjų 
aktyvinančios EGFR mutacijos nustatytos 108-iems, 106 pacientai įtraukti į tyrimą. Tiriamųjų charakteristikos: vidutinis amžius - 65 metai, 70,8 proc. moterų, 92,5 proc. IV stadijos, geros funkcinès būklès (tik 6,6 proc. 2 balai pagal ECOG), 94,4 nerūkantys ar metę rūkyti, delecija 19 egzone - 65,1 proc., mutacija 21 egzone - 31,1 proc. Rezultatai: bendras atsako dažnumas - 69,8 proc., ligos kontrolès dažnumas - 90,6 proc., išgyvenamumas be ligos progresavimo (mediana - 9,7 mèn., 12 mèn. - 38,5 proc.), bendras išgyvenamumas (mediana - 19,2 mèn., 12 mèn. 70,4 proc.). Dažniausiai pasitaikę nepageidaujami reiškiniai: išbèrimas $-44,9$ proc. (0 proc. $\geq$ III laipsnio), viduriavimas $-30,8$ proc. (3,7 proc. $\geq$ III laipsnio) [14].

\section{GYDYMAS EGFR TIROZINO KINAZĖS INHIBITORIAIS LIETUVOJE}

2012 metais paskelbti rezultatai pirmojo ir vienintelio Lietuvoje atlikto tyrimo, skirto įvertinti EGFR geno mutacijų dažnumą ir gydymo EGFR tirozino kinazès inhibitoriais efektyvumą sergant NSLPV. EGFR mutacijos buvo nustatytos 9,71 proc. tiriamųjų (10 iš 103), dažniau moterims ir nerūkantiems asmenims. Esant aktyvinančioms EGFR geno mutacijoms, reikšmingai didesnis atsako dažnumas ( 85,7 proc.) bei ilgesnis laikotarpis be ligos progresavimo (mediana nepasiekta) buvo grupejje pacientų, gydytu EGFR tirozino kinazès inhibitoriais, palyginti su gydytais chemoterapija (atitinkamai 32,9 proc. ir 5,6 mèn.) [15]. 2013-2014 metais paskelbti rezultatai tyrimų, kuriuose pirmą kartą apžvelgtas EGFR geno mutacijų dažnumas Europos šalių klinikinejje praktikoje, įtraukiant $\mathfrak{i}$ analizę ir Lietuvos mokslininkų duomenis. Šių tyrimų duomenimis, EGFR mutacijų dažnumas Europoje svyruoja nuo 4,5 iki 37 proc., vidutiniškai - 13,8 proc. [16, 17].

Atnaujintais 2014 metuc Lietuvos sveikatos mokslų universiteto Kauno klinikų duomenimis, EGFR geno mutacijų dažnumas tiriant nesmulkiųjų ir ne plokščiųjų ląstelių plaučių vèžiu sergančius ligonius yra 15,8 proc. Gydant šiuos pacientus EGFR tirozino kinazès inhibitoriais, jų išgyvenamumo be ligos progresavimo mediana buvo reikšmingai ilgesnè nei gydytų standartine chemoterapija (13,6 mèn. ir 5,6 mèn.), o kai kurių pacientų siekè net 21,2 mènesius (nepublikuoti duomenys).

Itvertinus EGFR tirozino kinazès efektyvumą, rekomenduojama dèl EGFR geno mutacijų ištirti ligonius, sergančius lokaliai išplitusiu (kai negalimas lokalus radikalus gydymas) ar metastaziniu NSLPV, kai numatomas gydymas EGFR tirozino kinazès inhibitoriais. Pacientų atranka molekuliniams tyrimams priklauso nuo plaučių vèžio histologinio tipo ir atliktos procedūros. Radikaliai rezekavus plaučių naviką operacijos metu rekomenduojama tirti adenokarcinoma ar adenokarcinomos komponentą turinčiu naviku (pvz., adenoskvamozine karcinoma) sergančius ligonius, o plokščiųjų ląstelių karcinoma, smulkiųjų ląstelių karcinoma ar didelių ląsteliụ karcinoma sergančius ligonius tirti nerekomenduojama.
Smulkiųjų biopsijų metu rekomenduojama tirti adenokarcinoma ar adenokarcinomos komponentą turinčiu naviku sergančius ligonius. Jei smulkiųjų biopsijų metu nustatoma plokščiųjų ląstelių karcinoma, didelių ląstelių karcinoma, nesmulkiųjų ląstelių karcinoma ar smulkiųjų ląstelių karcinoma, rekomenduojama tirti ligonius dèl EGFR mutacijuc tais atvejais, kai papildomais imunohistocheminiais tyrimais nustatoma adenokarcinomos komponentui būdingų imunohistocheminių požymių ar lieka nesmulkiųjų ląstelių karcinomos nepatikslintos kitaip diagnozè. Kai nepakanka tiriamosios medžiagos papildomiems imunohistocheminiams tyrimams ir nèra galimybès pakartoti biopsijos, dèl EGFR geno mutacijuc konsiliumo sprendimu galima tirti ligonius, sergančius plokščiųjų ląstelių karcinoma, didelių ląstelių karcinoma, nesmulkiųjų ląstelių plaučių karcinoma, neklasifikuojama kitaip, ar smulkiųjų ląstelių karcinoma, jei negalima paneigti adenokarcinomos komponento ir yra klinikiniu predikcinių tirozino kinazès inhibitorių veiksmingumo veiksnių (jaunas amžius, nerūkę ar buvę lengvi rūkoriai, per metus surūkydavę mažiau nei 15 cigarečių pakelių) [18].

\section{ATSPARUMO IŠSIVYSTYMAS GYDANT PIRMOS KARTOS EGFR TIROZINO KINAZĖS INHIBITORIAIS}

Nepaisant ženklaus klinikinio efektyvumo, daugumai plaučių vėžiu sergančiųjų, gydomų pirmos kartos EGFR tirozino kinazès inhibitoriais, liga pradeda progresuoti po 1-2 metų. Atlikę pakartotines biopsijas mokslininkai nustate keletą molekulinių pažaidų, atsakingų už atsparumo išsivystymą (MET amplifikaciją, HER2 amplifikaciją, transformaciją i smulkiųjų ląstelių plaučiuc vèžĭ, mezenchiminę epitelinę transformaciją ir kt.), iš kurių dažniausias (nustatomas per 60 proc. atvejų) yra naujos mutacijos T790M EGFR gene atsiradimas [19]. Atsiradus šiai naujai mutacijai pakinta EGFR tirozino kinazès domenas ir pirmos kartos EGFR tirozino kinazès inhibitoriai nebegali efektyviai jungtis ir slopinti šio receptoriaus veiklos [20].

Vienas iš būdų, bandant ịveikti šị atsparumo mechanizmą, buvo antros kartos EGFR tirozino kinazių (afatinibo, dakomitinibo), pasižyminčių negrịžtamu platesnio spektro ErbB šeimos receptorių slopinimu, įvedimas ị klinikinę praktiką. Ir nors antros kartos EGFR tirozino kinazès inhibitoriai buvo veiksmingi eksperimentiniuose ikiklinikiniuose tyrimuose bei gydant pirmos eilès plaučių vèži, jų efektyvumas gydant atsparų plaučiuc véži su nustatyta EGFR T790M mutacija buvo saikingas (atsako dažnis mažiau nei 10 proc., išgyvenamumas be ligos progresavimo mažiau nei 4 mènesiai) [21]. Pagrindinè to priežastis ta, kad plaučių véžiu sergančiųjų kliniškai toleruojama antros kartos EGFR tirozino kinazès inhibitorių dozė (kurią apibūdina nemutuoto EGFR slopinimas) buvo nepakankama atsparumo mutacijai T790M EGFR gene nuslopinti. 


\section{OSIMERTINIBAS - TREČIOS KARTOS EGFR TIROZINO KINAZĖS INHIBITORIUS}

Osimertinibui (Tagrisso, AZD9291) būdingas selektyvus negrižtamas poveikis tiek aktyvinančioms, tiek atsparioms EGFR geno mutacijoms (tarp ju T790M), bet jis praktiškai neblokuoja nemutavusių, vadinamojo laukinio tipo, EGFR geno receptorių, todèl nesukelia nepageidaujamo poveikio, būdingo pirmos ir antros kartos EGFR tirozino kinazès inhibitoriams (bèrimų, viduriavimo ir kt.).

Osimertinibas esant reikšmingam klinikiniam efektui buvo pagreitintai registruotas JAV ir Europos atsakingu isstaigu lokaliai progresavusio ir metastazavusio EGFR mutacijai T790M teigiamo NSLPV gydymui remiantis I ir II fazès klinikinių tyrimų rezultatais. İ šiuos klinikinius tyrimus įtraukti pacientai, kuriems plaučių vėžys progresavo gydant tirozino kinazès inhibitoriais ir kuriems nustatyta atspari EGFR T790M mutacija navikiniame audinyje. Šiuc klinikinių tyrimų duomenimis, stebètas atsako dažnis 6171 proc., ligos kontrolès dažnis 90-95 proc., atsako trukmè 7,8-12,4 mèn., išgyvenamumas be ligos progreso 8,6-13,5 mèn. Gydymas osimertinibu (Tagrisso) kliniškai gerai toleruojamas, nes III-IV laipsnio nepageidaujamų poveikiuc pasitaikè tik nuo 0 iki 1,2 proc. tiriamųjų [22, 23]. Atsparią EGFR mutaciją T790M galima nustatyti tiek navikiniame plaučiuc audinyje, tiek ligonių kraujo plazmoje. Pastarasis metodas ypač naudingas, nes plaučiu věžiui progresuojant ne visais atvejais yra immanomos pakartotinès biopsijos.

\section{APIBENDRINIMAS}

Taikinių terapija - tai kokybiškai naujas plaučių véžio gydymo standartas, pailginantis plaučių vẻžiu sergančių ligonių gyvenimo trukmę ir pagerinantis gyvenimo kokybę. Gefitinibas, pirmos kartos EGFR tirozino kinazès inhibitorius, yra efektyvus ir saugus pirmos eilès vaistas NSLPV gydyti ligoniams, kuriems nustatytos aktyvinančios EGFR geno mutacijos. Osimertinibas - kitas veiksmingas ir ypač gerai toleruojamas gydymo būdas gydant atsparų EGFR tirozino kinazès inhibitoriams plaučių vèži.

967.770,011/04/16/LT Publikaciją remia UAB „AstraZeneca Lietuva“.

\section{LITERATŪRA}

1. Jemal A, Murray E, et al. Cancer statistics, 2005. CA Cancer J Clin 2005; 55: 10-30.

2. Lietuvos Vèžio Registras. Pasiekta www.is.lt/cancer_reg

3. Schiller JH, Harrington D, Belani CP, et al. Comparison of four chemotherapy regimens for advanced non-small cell lung cancer. N Engl J Med 2002; 346: 92-98.

4. Kris MG, Natale RB, Herbst RS, et al. Efficacy of gefitinib, an inhibitor of the epidermal growth factor receptor tyrosine kinase, in symptomatic patients with non-small cell lung cancer: a randomised trial. JAMA. 2003; 290(16): 2149-58.

5. Fukuoka M, Yano S, Giaccone G, et al. Multi-institutional randomized phase II trial gefitinib for previouslytreated patients with advanced non-smallcell lung cancer. J Clin Oncol 2003; 21:2237-2246.

6. Herbst RS, Giaccone G, Manegold C, et al. Gefitinib in combination with gemcitabine and cisplatin in advanced nonsmall- cell lung cancer: a phase III trial - INTACT 1. J Clin Oncol 2004; 22:777-784.

7. Herbst RS, Giaccone G, Shiller JH, et al. Gefitinib in combination with paclitaxel and carboplatin in advanced nonsmall- cell lung cancer: a phase III trial - INTACT 2. J Clin Oncol 2004; 22:785-794

8. LynchTJ, Bell DW, Sordell R, et al. Activating mutations in the epidermal growth factor receptor underlying responsiveness of non-small-cell lung cancer to gefitinib. N Engl J Med. 2004; 350: 21292139

9. Paez JG, Janne PA, Lee JC, et al. EGFR mutations in lung cancer: correlation with clinical response to gefitinib therapy. Science. 2004; 304: 1497-1500.

10. Mok TS, Wu YL, Thongrrasert S, et al. Gefitinib or carboplatin- paclitaxel in pulmonary adenocarci- noma. N Engl J Med. 2009; 361: 947-957.

11. Han JY, Park K, Kim SW, et al. First-SIGNAL: first-line single- agent Iressa versus gemcitabine and cisplatin trial in never-smokers with adenocarcinoma of the lung. J Clin Oncol. 2012; 30: 1122-1128.

12. Mitsudomi $T$, Morita $S$, Yatabe $Y$, et al. Gefitinib versus cisplatin plus docetaxel in patients with non-small-cell lung cancer harbouring mutations of the epidermal growth factor receptor (WJTOG3405): an open label, randomised phase 3 trial. Lancet Oncol. 2010; 11: 121-128.

13. Maemondo M, Inoue A, Kobayashi K, et al. Gefitinib or chemotherapy for non-small-cell lung cancer with mutated EGFR. N Engl J Med. 2010; 362: 2380-2388.

14. Douillard JY, Ostoros G, Cobo M, et al. Efficacy, safety and tolerability results from a Phase IV open-label, single-arm, study of first-line gefitinib in Caucasian patients with EGFR mutation-positive non-small-cell lung cancer. European Multidisciplinary Conference in Thoracic Oncology (EMCTO) 2013.

15. Vaguliene $N$, Žemaitis $M$, Šarausakas V, et al. The role of mutation status of the epidermal growth factor receptor gene in advanced non-small cell lung cancer. Medicina (Kaunas) 2012; 48(4):175-81.

16. Szumera-Ciećkiewicz A, Olszewski WT, Tysarowski $A$, et al. EGFR mutation testing on cytological and histological samples in non-small cell lung cancer: a Polish, single institution study and systematic review of European incidence. Int J Clin Exp Pathol 2013; 6(12):2800-2812.

17. Hantson I, Dooms Ch, Verbeken $E$ et al. Performance of standard procedures in etection of EGFR mutations in daily practice in advanced NSCLC patients selected according to the ESMO guideline: a large Caucasian cohort study. Translational Respiratory Medicine 2014, 2:9.

18. Žemaitis M. (redaktorius). Plaučių vèžio diagnostikos ir gydymo rekomendacijos. Kaunas 2013; 67 psl.

19. Yu HE, Arcila ME, Rekhtman N, et al. Analysis of Tumor Specimens at the Time of Acquired Resistance to EGFR-TKI Therapy in 155 Patients with EGFR-Mutant Lung Cancers. Clin Cancer Res 2013, 19 (8): 2240-2247.

20. Yun $\mathrm{CH}$, Mengwasser $\mathrm{KE}$, Toms AV, et al. The T790M mutation in EGFR kinase causes drug resistance by increasing the affinity for ATP. Proc Natl Acad Sci USA 2008; 105: 2070-2075.

21. Miller VA, Hirsh V, Cadranel J, et al. Afatinib versus placebo for patients with advanced, metastatic non-small-cell lung cancer after failure of erlotinib, gefitinib, or both, and one or two lines of chemotherapy (LUX-Lung 1): a phase $2 \mathrm{~b} / 3$ randomised trial. Lancet Oncol 2012; 13: 528-538.

22. Jänne $P A, A h n M, K i m ~ D$, et al. A phase I study of AZD9291 in patients with EGFRTKIresistant advanced NSCLC - updated progressionfree survival and duration of response data. Presented at: European Lung Cancer Conference; April 1518, 2015; Geneva, Switzerland. Abstract LBA3.

23. Janne PA, Yang JC, Kim DW, et al. AZD9291 in EGFR inhibitor- resistant non-small-cell lung cancer. N Engl J Med 2015; 372: 1689-1699. 